\title{
Identification of Resistance to Maize rayado fino virus in Maize Inbred Lines
}

Jose Luis Zambrano, Department of Horticulture and Crop Science, The Ohio State University-Ohio Agriculture Research and Development Center (OSU-OARDC), Wooster, OH 44691, and Instituto Nacional Autónomo de Investigaciones Agropecuarias (INIAP), Programa Nacional del Maíz, Quito, Ecuador; David M. Francis, Department of Horticulture and Crop Science, OSU-OARDC, Wooster, OH 44691; and Margaret G. Redinbaugh, USDA, Agricultural Research Service, Corn, Soybean and Wheat Quality Research Unit and Department of Plant Pathology, OSU-OARDC, Wooster, OH 44691

\begin{abstract}
Zambrano, J. L., Francis, D. M., and Redinbaugh, M. G. 2013. Identification of resistance to Maize rayado fino virus in maize inbred lines. Plant Dis. 97:1418-1423.

Maize rayado fino virus (MRFV) causes one of the most important virus diseases of maize in America. Severe yield losses, ranging from 10 to $50 \%$ in landraces to nearly $100 \%$ in contemporary cultivars, have been reported. Resistance has been reported in maize populations, but few resistant inbred lines have been identified. Maize inbred lines representing the range of diversity in the cultivated types and selected lines known to be resistant to other viruses were evaluated to identify novel sources of resistance to MRFV. The virus was transmitted to maize seedlings using the vector Dalbulus maidis, and disease incidence and severity were evaluated beginning 7 days postinoculation.

ease incidence ranging from 21 to $96 \%$, and severity from 1.0 to 4.3 (using a 0 to 5 severity scale). A few genotypes, including CML333 and Ki11, showed intermediate levels of resistance, with 14 and $10 \%$ incidence, respectively. Novel sources of resistance, with incidence of less than $5 \%$ and severity ratings of 0.4 or less, included the inbred lines Oh1VI, CML287, and Cuba. In Oh1VI, resistance appeared to be dominant, and segregation of resistance in $\mathrm{F}_{2}$ plants was consistent with one or two resistance genes. The discovery of novel sources of resistance in maize inbred lines will facilitate the identification of virus resistance genes and their incorporation into breeding programs.
\end{abstract} Most of the 36 lines tested were susceptible to MRFV, with mean dis-
Maize rayado fino virus (MRFV) is one of the most important virus diseases of maize (Zea mays L.) in parts of Mexico, and Central and South America $(8,15,21,33)$. Severe yield losses, ranging from 10 to $50 \%$ in landrace populations to nearly $100 \%$ in some cultivars, have been reported $(12,38,40)$. First described in El Salvador (11), the disease is often found in plants co-infected with corn stunt spiroplasma (CSS; Spiroplasma kunkelii) and maize bushy stunt phytoplasma (MBSP; 'Candidatus Phytoplasma astris' subgroup 16SrI-B). Together, the three pathogens form an aggressive disease complex known as "achaparramiento" or red stunt (28).

MRFV is the type member of the genus Marafivirus. Virus particles are icosahedra approximately $30 \mathrm{~nm}$ in diameter (14). The virus genome is a 6,305 nucleotide monopartite, single stranded,

Corresponding author: M. G. Redinbaugh,

E-mail: peg.redinbaugh@ars.usda.gov

The U.S. Department of Agriculture (USDA) prohibits discrimination in all its programs and activities on the basis of race, color, national origin, age, disability, and where applicable, sex, marital status, familial status, parental status, religion, sexual orientation, genetic information, political beliefs, reprisal, or because all or part of an individual's income is derived from any public assistance program. (Not all prohibited bases apply to all programs.) Persons with disabilities who require alternative means for communication of program information (Braille, large print, audiotape, etc.) should contact USDA's TARGET Center at (202) 720-2600 (voice and TDD). To file a complaint of discrimination, write to USDA, Director, Office of Civil Rights, 1400 Independence Avenue, S.W., Washington, D.C. 20250-9410, or call (800) 795-3272 (voice) or (202) 720-6382 (TDD). USDA is an equal opportunity provider and employer.

* The $\boldsymbol{e}$-Xtra logo stands for "electronic extra" and indicates that Figure 1 appears in color online.

Accepted for publication 29 March 2013.

http://dx.doi.org/10.1094/PDIS-01-13-0037-RE

This article is in the public domain and not copyrightable. It may be freely reprinted with customary crediting of the source. The American Phytopathological Society, 2013. positive sense RNA (18). Genetic variation among MRFV populations has been described, with four groups or races occurring in the Americas (6). In nature, MRFV is transmitted by the corn leafhopper Dalbulus maidis (Homoptera: Cicadellidae), and it replicates in both its host plant and insect vector (13). Nymphs and adults can transmit MRFV to plants, but the virus is not transmitted transovarially. The latent period between virus acquisition and subsequent transmission by vectors is temperature dependent, and varies from 8 to 37 days. Under experimental conditions, MRFV also can be transmitted by the leafhoppers D. elimatus, Stirellus bicolor, and Graminella nigrifrons. The disease is not transmitted by seed (29). Typical disease symptoms appear on young leaves as small chlorotic spots that become elongated and more numerous along leaf veins with age $(14,37)$. Susceptible plants infected at early developmental stages are reduced in height and develop ears with few or no seed, resulting in yield reduction $(15,40)$.

There have been several attempts to identify sources of genetic resistance to MRFV since the identification of the virus in Central America (11). Several hundred cultivars, from landraces to inbred lines, have been reported as susceptible to MRFV infection, but only three tropical accessions, Saint Croix, INIAP176, and CML459, were identified as resistant $(3,10,29,32,37,39)$. Saint Croix and INIAP176 are open pollinated cultivars, complicating the use of this germplasm for genetic analysis. Although CML459 is a highland inbred line, no mapping populations using this line are available. The objective of this study was to identify novel sources of resistance to MRFV in a set of tropical and temperate inbred lines that will support further genetic analysis and that may be directly used in breeding programs.

\section{Materials and Methods}

Maize germplasm. Seeds of 36 maize accessions were obtained from the North Central Regional Plant Introduction Station (NCRPIS) and the International Maize and Wheat Improvement Center (CIMMYT), or were maintained by the USDA, ARS Corn, Soybean and Wheat Quality Research Unit (CSWQRU) in Wooster, $\mathrm{OH}$ as indicated in Table 1. Accessions were selected based on the availability of mapping populations and/or resistance to other virus diseases, with most of the selected genotypes corre- 
sponding to the founders of the Nested Association Mapping (NAM) population $(27,41)$. The susceptible genotypes Spirit (Syngenta, ID) and B73, and the resistant cultivars Saint Croix (PI484036), INIAP180 (derived from INIAP-176), and CML459 were used as controls.

Virus isolate and insect vector. The sweet corn hybrid Spirit was used for virus maintenance. A MRFV isolate collected in Texas by Bradfute and others (2) was used. The isolate was stored in liquid nitrogen, then transmitted to germinating maize kernels using vascular puncture inoculation $(22,26)$, and subsequently maintained by serial transmission to maize seedlings using a $D$. maidis colony originally collected from California (29). Viruliferous $D$. maidis were obtained by allowing adults reared on healthy maize to feed on MRFV-infected plants for 26 days before being used for inoculation $(3,37)$.

Evaluation of maize responses to MRFV. Single seeds of each accession were planted into $16.4 \times 2.5 \mathrm{~cm}$ "Cone-tainers" (Stuewe and Sons Inc., Tangent, OR) containing greenhouse soil (Potting Mix, Lawn Products Inc., Marysville, $\mathrm{OH}$ ). Six days after planting, 10 uniform seedlings of each accession were selected and randomized in an alpha-lattice design (described below) distributed among four $30.5 \times 30.5 \mathrm{~cm}$ racks (Stuewe and Sons), each holding 90 seedlings. Each rack was placed into a Dacron cage (24) along with 10 Spirit seedlings. Then, 500 viruliferous $D$. maidis were introduced in each cage for an inoculation access period (IAP) of 7 days in a growth chamber $\left(12 \mathrm{~h} \mathrm{light} /\right.$ dark periods at $25^{\circ} \mathrm{C}$, with $\left.600 \mu \mathrm{mol} \cdot \mathrm{m}^{-2} \cdot \mathrm{s}^{-1}\right)$. After the IAP, plants were fumigated and transferred to a growth chamber under similar conditions for symptom development.

Symptom evaluation. Following the end of the IAP, which was defined as 0 days postinoculation (dpi), disease incidence and severity were observed daily and recorded at 7, 14, and 21 dpi. Incidence was estimated based on the number of plants for each accession showing symptoms, and severity was evaluated on the two uppermost leaves of individual plants using a 6-point scale: 0 , no symptoms; 1 , chlorotic spots covering $<25 \%$ of the leaf surface; 2 , bright chlorotic spots and short stripes covering 25 to $50 \%$ of the leaf surface; 3 , bright chlorotic spots and stripes on 50 to $75 \%$ of the leaf surface; 4, bright chlorotic spots and stripes covering more than $75 \%$ of the leaf surface; and 5 , a previously symptomatic plant that died (Fig. 1; see online version for color images). The area under the disease progress curve (AUDPC) was calculated from the incidence data on the 10 plants of each genotype at 7,14 , and 21 days after IAP. Disease severity indices (DSI) were calculated from the severity ratings at 21 dpi using the formula (16):

$$
\text { DSI }=\sum \frac{(\text { Severity class } \times \text { number of plants in class }) \times 100}{\text { Total number of plants } \times 5}
$$

Table 1. Responses of maize accessions to Maize rayado fino virus (MRFV) inoculation

\begin{tabular}{|c|c|c|c|c|c|}
\hline \multirow[b]{2}{*}{ Accession } & \multirow[b]{2}{*}{ Source $^{b}$} & \multicolumn{4}{|c|}{ Disease symptoms score ${ }^{a}$} \\
\hline & & Incidence $(\%)$ & Severity $^{c}$ & AUDPC $^{d}$ & DSI $^{\mathrm{e}}$ \\
\hline CML103 & $\mathrm{N}$ & 96 & 3.0 & 36.4 & 57.9 \\
\hline B73 & $\mathrm{N}$ & 80 & 2.7 & 36.0 & 41.3 \\
\hline Spirit & $\mathrm{S}$ & 78 & 3.0 & 36.0 & 48.1 \\
\hline Ms71 & $\mathrm{N}$ & 70 & 3.3 & 34.1 & 46.7 \\
\hline Oh28 & $\mathrm{U}$ & 69 & 3.0 & 23.4 & 40.5 \\
\hline CML228 & $\mathrm{N}$ & 67 & 2.0 & 18.8 & 26.0 \\
\hline Pool12 & $\mathrm{C}$ & 63 & 2.2 & 22.2 & 28.0 \\
\hline HP301 & $\mathrm{N}$ & 62 & 3.8 & 27.6 & 48.8 \\
\hline P39 & $\mathrm{N}$ & 59 & 3.0 & 18.2 & 39.2 \\
\hline CML247 & $\mathrm{N}$ & 54 & 3.2 & 12.9 & 33.1 \\
\hline Tx303 & $\mathrm{N}$ & 53 & 3.3 & 17.7 & 37.6 \\
\hline M37W & $\mathrm{N}$ & 52 & 2.7 & 24.0 & 40.3 \\
\hline $\mathrm{Ki} 3$ & $\mathrm{~N}$ & 50 & 2.2 & 12.1 & 23.0 \\
\hline Oh7B & $\mathrm{N}$ & 48 & 3.2 & 13.2 & 31.7 \\
\hline NC350 & $\mathrm{N}$ & 47 & 3.0 & 13.2 & 28.0 \\
\hline $\mathrm{Il} 14 \mathrm{H}$ & $\mathrm{N}$ & 44 & 4.3 & 20.6 & 38.9 \\
\hline NC358 & $\mathrm{N}$ & 39 & 2.9 & 15.1 & 23.6 \\
\hline CML277 & $\mathrm{N}$ & 35 & 2.9 & 10.5 & 25.1 \\
\hline B97 & $\mathrm{N}$ & 32 & 3.6 & 10.2 & 22.7 \\
\hline M162W & $\mathrm{N}$ & 30 & 4.0 & 12.6 & 22.4 \\
\hline CML322 & $\mathrm{N}$ & 30 & 2.1 & 10.6 & 12.7 \\
\hline Pool11 & $\mathrm{C}$ & 30 & 3.0 & 12.7 & 18.0 \\
\hline CML202 & $\mathrm{C}$ & 27 & 1.1 & 5.4 & 6.1 \\
\hline Tzi8 & $\mathrm{N}$ & 25 & 2.0 & 4.8 & 10.2 \\
\hline DR & $\mathrm{U}$ & 24 & 1.0 & 3.2 & 4.8 \\
\hline Mo18W & $\mathrm{N}$ & 23 & 3.3 & 8.5 & 16.7 \\
\hline CML69 & $\mathrm{N}$ & 22 & 1.1 & 3.7 & 7.0 \\
\hline CML52 & $\mathrm{N}$ & 21 & 2.5 & 5.4 & 9.3 \\
\hline CML333 & $\mathrm{N}$ & 14 & 2.2 & 3.2 & 6.0 \\
\hline Ki11 & $\mathrm{N}$ & 10 & 0.4 & 2.1 & 2.8 \\
\hline INIAP180 & $\mathrm{C}$ & 4 & 0.7 & 1.8 & 1.8 \\
\hline Oh1VI & $\mathrm{U}$ & 3 & 0.3 & 0.6 & 0.7 \\
\hline CML287 & $\mathrm{C}$ & 0 & 0.0 & 0.0 & 0.0 \\
\hline CML459 & $\mathrm{C}$ & 0 & 0.0 & 0.0 & 0.0 \\
\hline Cuba & $\mathrm{U}$ & 0 & 0.0 & 0.0 & 0.0 \\
\hline Saint Croix & $\mathrm{N}$ & 0 & 0.0 & 0.0 & 0.0 \\
\hline Mean & & 38 & 2.2 & 13.2 & 22.1 \\
\hline Tukey ${ }^{\mathrm{f}}$ & & 51 & 2.9 & 20.9 & 40.8 \\
\hline
\end{tabular}

${ }^{a}$ Disease symptoms scored at 21 days postinoculation (dpi). Data presented are the means of three replications with 10 plants per replication.

${ }^{\mathrm{b}}$ Sources of seeds. N, North Central Regional Plant Introduction Station (Iowa); C, International Maize and Wheat Improvement Center (Mexico); S, Syngenta (Idaho); U, USDA-ARS Corn, Soybean and Wheat Quality Research Unit (Ohio).

${ }^{\mathrm{c}}$ Severity was evaluated on a scale 0 to 5 , where $0=$ no disease symptoms and $5=$ dead after developing disease symptoms.

d AUDPC, area under the disease progress curve calculated from the incidence values scored at 7, 14, and 21 dpi, as outlined in Materials and Methods.

${ }^{\mathrm{e}}$ DSI, disease severity index at $21 \mathrm{dpi}$.

${ }^{\mathrm{f}}$ Minimum significant difference according to Tukey's studentized range test $(P=0.05)$. 
MRFV detection with ELISA. The presence of MRFV in putatively resistant accessions was evaluated using enzyme-linked immunosorbent assay (ELISA). Ten seedlings of each accession were inoculated and evaluated for symptom development as outlined above. B73, Spirit, Oh28, and Saint Croix were included as susceptible and resistant controls. At $21 \mathrm{dpi}$, leaf samples $(0.15 \mathrm{~g})$ were taken from the youngest expanding leaf, pooled by accession, and stored at $-20^{\circ} \mathrm{C}$ prior to analysis. Protein A sandwich (PAS)ELISA was carried out as previously described (9), using MRFV antisera (2) at a 1:2,000 dilution. Absorbance of the samples and the concentration of virus were determined as previously described for Maize fine streak virus (36). The experiment was replicated four times.

Experimental design and data analysis. An incomplete block design (alpha-lattice) $(1,30)$ with three replications was used to evaluate the incidence, severity, and AUDPC of MRFV for the 36 maize accessions. To accommodate the size of transmission cages, each replication was divided into four incomplete blocks containing 10 individuals for each of nine accessions plus 10 susceptible controls. Analysis of variance (ANOVA) for incidence, severity, AUDPC, and DSI were calculated using the PROC MIXED function of SAS (SAS Institute, Inc., Cary, NC). Maize accession was a fixed factor, and replicate and block were treated as random factors. ELISA responses were analyzed using PROC GLM. Means separations between genotypes were estimated using Tukey's test $(P=0.05)$. Pearson correlation analysis was used to assess the relationship between the variables in pair-wise comparisons.

Inheritance of resistance. To evaluate the inheritance of resistance to MRFV, $40 \mathrm{~F}_{1}$ and $100 \mathrm{~F}_{2}$ seedlings from single ears derived from an Oh28 $\times$ Oh1VI cross, as well $30 \mathrm{Oh} 28$ and Oh1VI seedlings were inoculated and evaluated for symptom incidence and severity as outlined above. Data presented are for two independent replications, with seedlings that died without developing disease symptoms being removed from the analysis. For disease incidence in the $\mathrm{F}_{2}$ population, a chi-square test was conducted to assess significance of Mendelian segregation ratios.

\section{Results}

Responses of maize accessions to inoculation with MRFV. The first disease symptoms in susceptible control genotypes were observed between 4 and 5 dpi. A large proportion (75 and $77 \%$, respectively) of Spirit and B73 seedlings became symptomatic, with a disease severity rating of 2 at 7 dpi (Figs. 1 and 2). Incidence and severity were similar in both susceptible lines at all rating dates, indicating the disease transmission protocol was effective. Disease incidence and severity in susceptible controls did not increase after $7 \mathrm{dpi}$ and $14 \mathrm{dpi}$, respectively (Fig. 2). For all lines, incidence and severity were rated up to $21 \mathrm{dpi}$, in order to detect late developing infections. However, problems with longer-term maintenance of the plants under the growth chamber conditions required by APHIS permits prevented ratings beyond $21 \mathrm{dpi}$. Incidence and severity at 7, 14, and 21 dpi were significantly correlated $(P<$ 0.0001 ), suggesting this period was sufficient for disease evaluation.

There was significant genetic variation $(P<0.001)$ among the 36 maize accessions at $21 \mathrm{dpi}$ for incidence, severity, AUDPC, and DSI (Table 1). The residual plots of the variance indicated a linear relationship between the observed and predicted residuals, and no clear pattern for the plots involving standardized residuals. In addition, distribution of variable means for the accessions resembled a normal distribution (data not shown). Thus, homogeneity of variance and normal distribution were assumed. Although adjusted means were estimated from the alpha lattice design, the means for three replications are presented since there was no difference in the ranking of the resistant genotypes using calculated or adjusted means. Incidence, severity, AUDPC, and DSI were highly correlated $(P<0.001)$, with correlation coefficients ranging from 0.6 to 0.9 , suggesting that the most susceptible and most resistant accessions would be identified using incidence, severity, AUDPC, or DSI (data not shown). In particular, AUDPC and DSI were highly correlated (correlation coefficient of $0.95, P<0.0001$ ). The ranking of resistant accessions for these two traits did not differ (Table 1), so further discussion will be limited to the AUDPC trait.

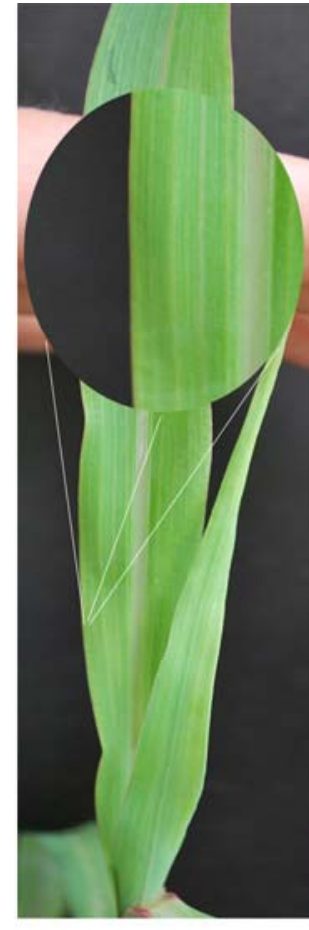

0

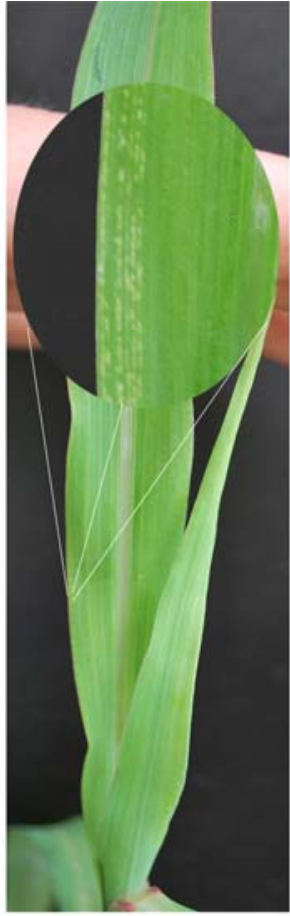

1

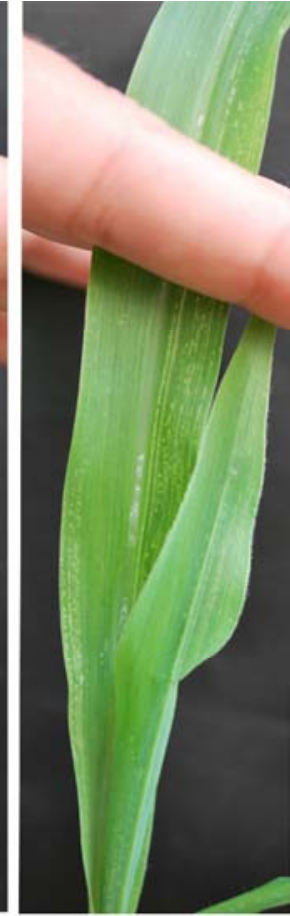

2

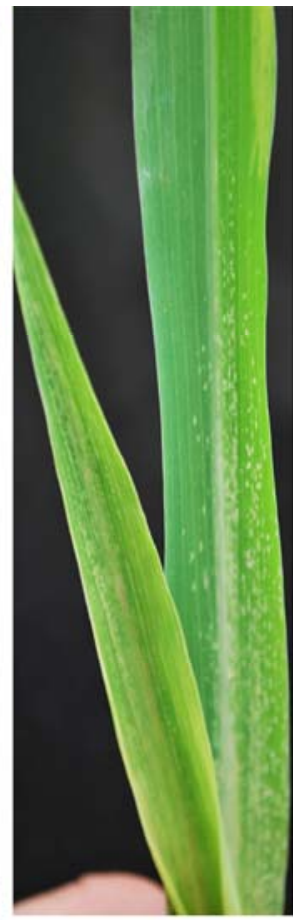

3

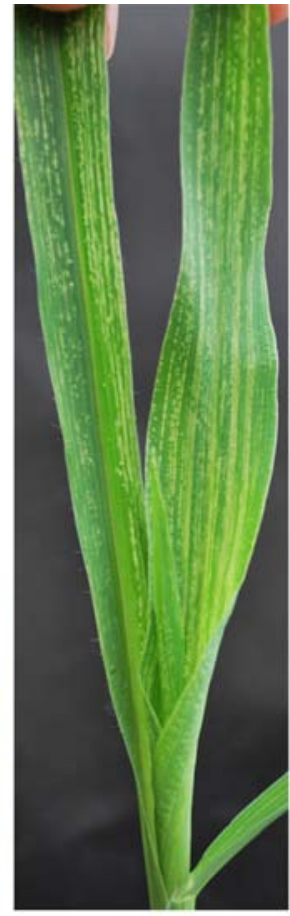

4

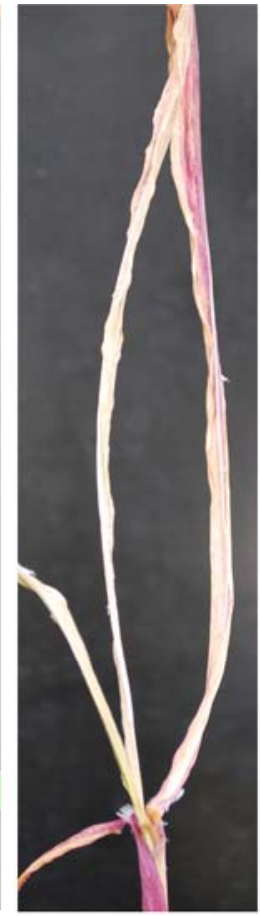

5

Fig. 1. Symptom severity scale used to evaluate the response of maize seedlings to inoculation with Maize rayado fino virus (MRFV). In the 0 to 5 scale, $0=$ no symptoms, 1 $=$ chlorotic spots encompassing 0 to $25 \%$ of the two upper leaves; $2=$ bright chlorotic spots and short stripes covering between 25 and $50 \%$ of the two upper leaves; $3=$ vivid chlorotic spots and stripes along the leaf veins, covering between 50 and $75 \%$ of the two upper leaves; $4=$ intense stripes covering more than $75 \%$ of the two upper leaves; and $5=$ dead plant after being scored as symptomatic 
Most of the accessions became infected with MRFV. While the susceptible controls B73 and Spirit had high symptom incidence and severity, fewer than $5 \%$ of seedlings in accessions previously identified as resistant (INIAP-180, CML459, and Saint Croix) became symptomatic, and severity ratings for these lines were $\leq 1.0$. Similarly, susceptible controls had AUDPC values of 36.0, and resistant controls had AUDPC values of 1.8 or less. Thus, the controls behaved as predicted from previous disease resistance tests $(3,37,39)$. Disease incidence in CML103, Ms71, Oh28, CML228, Pool12, HP301, P39, CML247, Tx303, M37W, Ki3, Oh7B, NC350, IL14H, NC358, CML277, B97, M162W, CML322, and Pool11 was similar to that in susceptible controls $(P>0.05)$. Disease incidence, severity, and AUDPC scores ranged from 30 to $96 \%, 2.1$ to 4.3 , and 10.6 to 36.4 , respectively, in this group of accessions. Although CML202, Tzi8, DR, Mo18W, CML69, CML52, and CML333 had significantly lower disease incidence and AUDPC scores than the susceptible controls, disease severity in these accessions was similar to the susceptible controls (Table 1). In contrast, in accessions Ki11, INIAP-180, and Oh1VI, symptom incidence was less than $10 \%$, mean severity ratings were less than 0.7, and AUDPC scores were less than 2.1, significantly lower than those in the susceptible controls. Further, CML287, CML459, Cuba, and Saint Croix developed no disease symptoms during the 21-day rating period (Table 1).
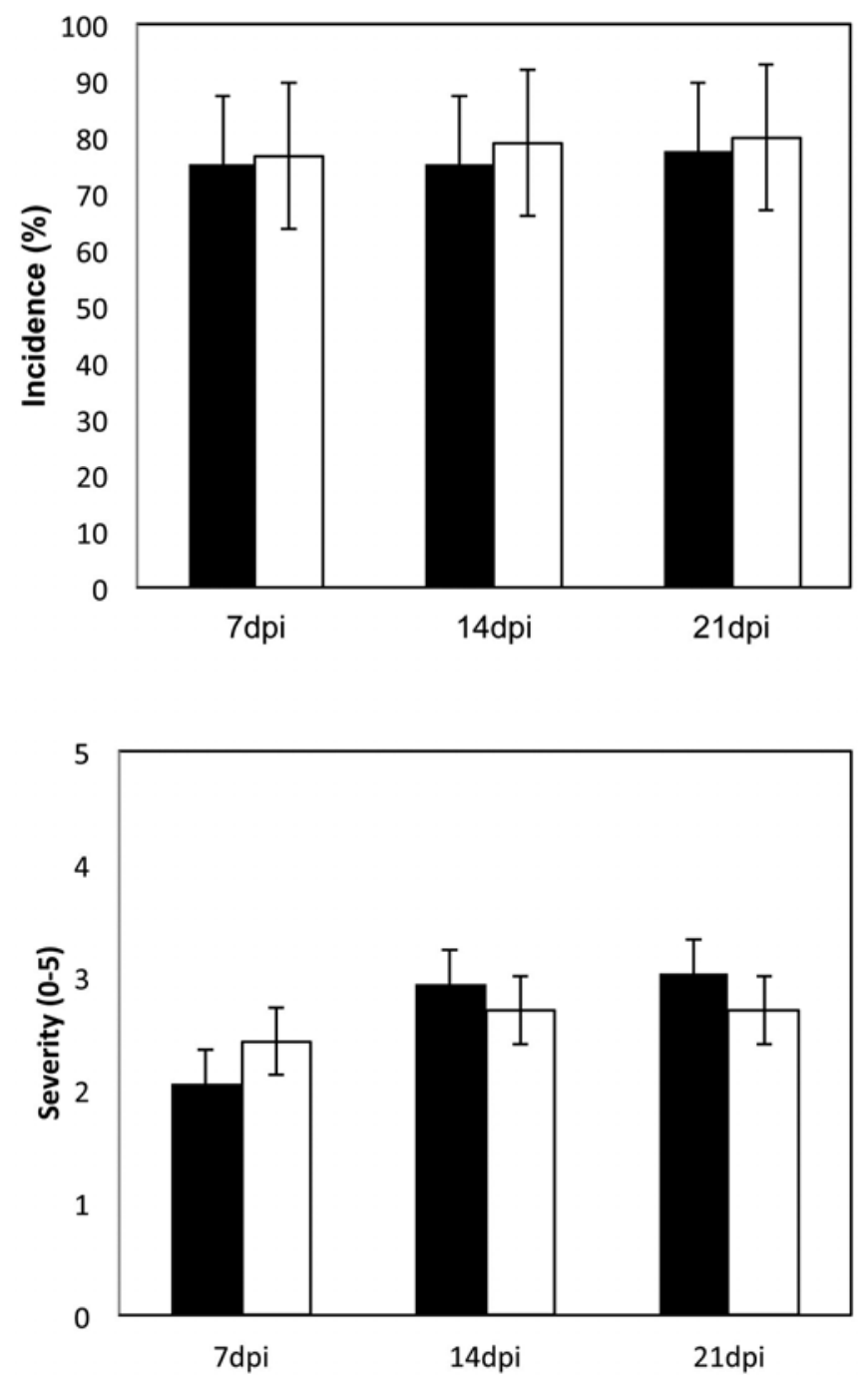

Fig. 2. Maize rayado fino virus (MRFV) disease progress in susceptible maize accessions. Symptoms were evaluated in maize Spirit and B73 at 7, 14, and 21 days postinoculation. Data presented are the means \pm S.D. for three replications with 10 plants per replication. Upper panel, Incidence presented as the percentage of plants with any symptoms. Lower panel, Mean severity rating of symptomatic plants using a rating scale of 0 to 5 , where $0=$ no disease symptoms and $5=$ plant dead.
A semi-quantitative PAS-ELISA was used to confirm that MRFV was not present in putatively resistant lines. Virus concentrations in the upper noninoculated leaves indicated significant MRFV concentrations in the susceptible controls (Fig. 3). In contrast, CML287, Cuba, Oh1VI, and Saint Croix were similar to noninoculated control plants in this assay. These results indicated that virus was not detected in accessions with few or no symptoms.

Inheritance of resistance to MRFV in Oh1VI. Only a few seedlings of $\mathrm{F}_{1}$ plants derived from a cross of Oh1VI $\times \mathrm{Oh} 28$ developed limited disease symptoms during the 21-day evaluation period after MRFV inoculation (Table 2). In these experiments, $23 \%$ of $\mathrm{F}_{2}$ seedlings developed symptoms. The mean severity ratings for symptomatic $F_{1}$ and $F_{2}$ plants were 1.7 and 2.8, respectively. Infection and disease severity in the parental lines were similar to the previous experiment (Table 1), with Oh1VI developing no disease symptoms, and $61 \%$ of Oh28 seedlings developing symptoms with a severity rating of 3.3 in symptomatic plants (Table 2). For $200 \mathrm{~F}_{2}$ seedlings inoculated over two replications, 18 died prior to 21 dpi without developing disease symptoms, and these were removed from the analysis. Of the remaining plants, 140 developed no symptoms and 42 developed symptoms with an average severity rating of 2.8 . The observed healthy:symptomatic ratio was consistent with a $3: 1$ or $13: 3$ segregation ratio in chisquare tests $(P$ value $>0.1)$, but differed from 15:1, 7:5, and 9:7 segregation ratios $(P$ value $<0.0001)$.

\section{Discussion}

MRFV is one of the most important virus diseases affecting maize in the Americas, from Argentina to the southern United States $(15,21,33)$. The impact of the disease is greater in the highlands of Mexico and in Central and South America, where it is usually present as a disease complex called "achaparramiento" or red stunt (39). The complex is caused by the presence MRFV and two additional pathogens, CSS and MBSP $(15,17)$. A number of CSS- and MBSP-resistant cultivars are available $(4,35,39)$, but genotypes resistant to MRFV are scarce. Only a few MRFV-resistant lines have been identified, and the genetic basis of resistance has not been described $(3,39)$. One reason for this lack of information is the heterogeneous nature of previously identified sources of resistance. For example, Saint Croix (landrace) and INIAP176 (open pollinated) are outcrossing populations, making

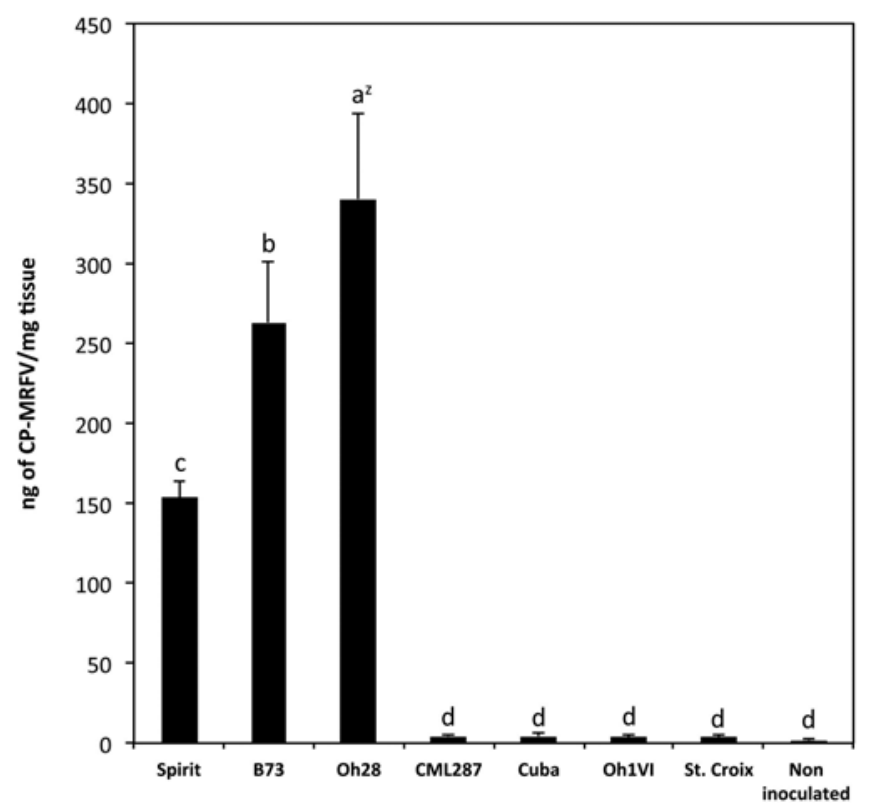

Fig. 3. Maize rayado fino virus (MRFV) antigen in maize leaves estimated with semi-quantitative protein A sandwich-enzyme-linked immunosorbent assay. Titer was estimated in selected maize lines at 21 days postinoculation. Data presented are the mean \pm S.D. for four replications with 10 plants per replication. Bars labeled with the same letter are not significantly different (Tukey's test, $P=0.05$ ). 
Table 2. Inheritance of resistance to Maize rayado fino virus (MRFV) in $\mathrm{F}_{1}$ and $\mathrm{F}_{2}$ maize populations derived from the resistant Oh1VI and the susceptible Oh28

\begin{tabular}{|c|c|c|c|c|c|c|c|c|c|}
\hline \multirow[b]{2}{*}{ Genotype } & \multirow[b]{2}{*}{$\mathrm{N}^{\mathrm{a}}$} & \multirow{2}{*}{$\begin{array}{c}\text { Incidence } \\
(\%)^{\mathbf{b}}\end{array}$} & \multirow{2}{*}{$\begin{array}{l}\text { Severity } \\
(0-5)^{\mathrm{c}}\end{array}$} & \multicolumn{6}{|c|}{ Severity class $^{\mathrm{d}}$} \\
\hline & & & & $\mathbf{0}$ & 1 & 2 & 3 & 4 & 5 \\
\hline $\mathrm{F}_{1}$ & $3 / 80$ & $4(0-8)$ & 1.7 & 77 & 1 & 2 & & & \\
\hline $\mathrm{F}_{2}$ & $42 / 182^{\mathrm{e}}$ & $23(15-31)$ & 2.8 & 140 & & 11 & 29 & 2 & \\
\hline Oh1VI & $0 / 50$ & $0(0-0)$ & 0.0 & 50 & & & & & \\
\hline Oh28 & $35 / 58$ & $61(60-61)$ & 3.3 & 23 & & 1 & 25 & 7 & 2 \\
\hline
\end{tabular}

a Number of seedlings with disease symptoms/total number of seedlings evaluated in two independent replications.

${ }^{\mathrm{b}}$ Proportion of plants showing any disease symptom at 21 days postinoculation (dpi). Data presented are the mean (range) from two replications.

${ }^{\mathrm{c}}$ Symptom severity at $21 \mathrm{dpi}$ on a 0 to 5 scale, where $0=$ no disease symptoms and $5=$ dead after developing disease symptoms. Data presented are the mean of symptomatic plants.

${ }^{\mathrm{d}}$ Number of individuals in each severity class at $21 \mathrm{dpi}$.

${ }^{\mathrm{e}}$ Fit 3:1 and 13:3 resistant:susceptible ratios according to chi-square test $(P>0.05)$.

genetic analyses difficult, and no recombinant populations derived from inbred lines (e.g., CML459) suitable for genetic analysis are available. In this study, we identified several new sources of MRFV resistance in maize germplasm, and determined that resistance in one inbred line is likely to be the result of one or a few resistance genes.

The susceptible responses of B73 and Spirit to inoculation with MRFV were expected based on previous results indicating little resistance to the virus in temperate germplasm $(23,37)$. MRFV resistance in Saint Croix and CML459 was confirmed, with no symptoms developing on either genotype under growth chamber conditions. Comparison of these results with those of previous studies, in which relatively high ELISA values were reported in Saint Croix and a few plants developed mild symptoms of CML459 late in infection (39), suggest that environment plays a role in MRFV resistance in these accessions.

Most of the lines tested were susceptible to MRFV, with incidence ranging from 20 to $96 \%$. The tropical lines Ki11 and CML333, which were included as founders of the NAM population, had an intermediate response to MRFV inoculation with disease incidence of 10 and $14 \%$, respectively (Table 1); however, disease severity in CML333 was not different from the susceptible controls. It remains to be determined whether these intermediate responses are a result of partial resistance to the virus, resistance to insect inoculation, or some mechanism that reduced transmission rates in these lines. Although Ki11 $\times$ B73 and CML333 $\times$ B73 populations could be used to map the location of loci conferring resistance, the intermediate responses to MRFV inoculation could reduce the power for QTL detection. Additionally, incomplete resistance phenotypes are usually conditioned by many loci with small effects (31), which are less amenable to manipulation in a breeding context. Nonetheless, the availability of linkage maps, genotypic data, and available recombinant inbred populations derived from these lines could be valuable for understanding MRFV resistance, especially in combination with mapping in other populations derived from highly resistant lines.

Novel sources of resistance to MRFV identified in the inbred lines Oh1VI, CML287, and Cuba were highly resistant to MRFV with ELISA responses and symptom development similar to healthy noninoculated control plants (Fig. 3). Interestingly, all lines identified as highly resistant in this study were derived from germplasm originating in the Caribbean. Oh1VI and Saint Croix were developed or collected from the Virgin Islands $(3,25)$, and Cuba was derived from a Cuban open pollinated population (M. G. Redinbaugh, unpublished results). CML287 is derived from CIMMYT population 24, originally developed from germplasm collected in eastern Mexico and Antigua (7). INIAP180 was derived from the MRFV-resistant open pollinated variety INIAP176 (3), and has germplasm from the highlands of El Salvador, Guatemala, and Honduras, in its genetic background (5). Notably, Oh1VI is resistant to Maize chlorotic dwarf virus (19), Maize dwarf mosaic virus and Sugar cane mosaic virus (20), Maize fine streak virus (34), and Maize necrotic streak virus (23). These observations suggest the importance of Central
American and Caribbean maize germplasm as sources of resistance to viral diseases.

Resistance to MRFV conferred by Oh1VI was successfully transmitted to $F_{1}$ and $F_{2}$ progenies. Symptom development in $F_{1}$ plants was similar to the resistant parent, suggesting resistance may be dominant. Resistance segregated in the $F_{2}$ population consistently with $3: 1$ and 13:3 segregation ratios (Table 2). However, because of the relatively small number of $F_{2}$ plants tested, it is possible that disease escapes may have interfered with determining the ratio of resistant to susceptible plants. If MRFV transmission to $F_{2}$ plants was the same as that observed for Oh28 (61\%), and we therefore assumed a disease escape rate of $39 \%$, then the observed segregation would fit both 7:5 and 9:7 segregation ratios $(P>0.1)$. While it is not possible to identify the number of genes involved in MRFV resistance from these experiments, our results suggest that one or two gene models are sufficient to explain the resistance conferred by Oh1VI. Further analysis to identify and map gene(s) conferring resistance to MRFV will be required to provide more definitive information.

It is not known whether the resistance sources identified in this study will be effective against all described MRFV isolates (6). However, previously identified MRFV-resistant lines had similar responses to the U.S. isolate used in this study and the Mexican or Costa Rican MRFV isolates used in other studies $(3,39)$. The isolate used for these studies was originally collected from Texas, where MRFV isolates were subsequently shown to belong to the same phylogenetic group as those from Mexico and Central America (6), and this could explain the similar responses. It would be of interest to determine whether resistance to phylogenetically distinct isolates from South America follows a similar pattern. In summary, we have confirmed previously reported sources of resistance to MRFV and identified three resistant maize inbred lines that could be directly used in national programs for development of maize hybrids or open pollinated varieties with increased resistance to MRFV.

\section{Acknowledgments}

We thank M. Jones (USDA-ARS) for valuable discussion and for providing seeds of inbred lines and $F_{1}$ and $F_{2}$ populations. We thank S. Taba from CIMMYT for helpful discussion and for providing seed. We also thank C. Gardner from NCRPIS for seed of the NAM founder lines, and Michele Gardiner (Syngenta Seeds Inc.) for Spirit sweet corn seed. We are grateful to Charlie Summers, UC-Riverside, CA for providing the Dalbulus maidis, to J. Todd (USDAARS) for maintaining the insect colony, and to K. Willie (USDA-ARS) for technical assistance. J. L. Zambrano thanks the Instituto Nacional Autónomo de Investigaciones Agropecuarias (INIAP), Ecuador for a fellowship to support his Ph.D. studies.

\section{Literature Cited}

1. Barreto, H., Edmeades, G., Chapman, S., and Crossa, J. 1997. The alpha lattice design in plant breeding and agronomy: Generation and analysis. Pages 544-551 in: Developing Drought and Low N-tolerant Maize. G. Edmeades, M. Banziger, H. Mickelson, and C. Peña-Valdivia, eds. CIMMYT, Mexico DF.

2. Bradfute, O. E., Toler, R. W., Boothroyd, C. W., Robertson, D. C., Nault, L. R., and Gordon, D. T. 1979. Identification of Maize rayado fino virus in the United States. Plant Dis. 64:50-53. 
3. Bustamante, P. I., Ramirez, P., and Hammond, R. 1998. Evaluation of maize germ plasm for resistance to Maize rayado fino virus. Plant Dis. 82:50-56.

4. Carpane, P. D. 2007. Host resistance and diversity of Spiroplasma kunkelii as components of corn stunt disease. Ph.D. thesis. Oklahoma State University, Stillwater.

5. Caviedes, M. 1986. INIAP-180: Nueva variedad de maíz de alto rendimiento. INIAP, Boletin divulgativo 180.

6. Chicas, M., Caviedes, M., Hammond, R., Madriz, K., Albertazzi, F., Villalobos, H., and Ramírez, P. 2007. Partial characterization of Maize rayado fino virus isolates from Ecuador: Phylogenetic analysis supports a Central American origin of the virus. Virus Res. 126:268-276.

7. CIMMYT. 1981. Report on maize improvement: 1980-81. CIMMYT, Mexico DF.

8. De-Oliveira, E., Duarte, A. P., De-Carvalho, R., and De-Oliveira, A. C. 2004. Molicutes e virus na cultura do milho no Brasil: Caracterizacao e factores que afetam sua incidencia. Page 17 in: Doencas en Milho. Molicutes, Virus, Vetores e Mancha por Phaeosphaeria. E. De-Oliveira and C. M. DeOliveira, eds. Embrapa Informacao Tecnologica, Brasilia.

9. Edwards, M. L., and Cooper, J. I. 1985. Plant virus detection using a new form of indirect ELISA. J Virol. Methods 11:309-319.

10. Espinoza, A. M., and Gamez, R. 1980. La ultraestructura de la superficie foliar de cultivares de maíz infectados con el virus del rayado fino. Turrialba 30:413-420.

11. Gamez, R. 1969. A new leafhopper-borne virus of corn in Central America. Plant Dis. Rep. 12:929-932.

12. Gamez, R. 1983. The ecology of Maize rayado fino virus in the American tropics. Pages 268-274 in: Plant Virus Epidemiology. in: R. T. Plumb and J. M. Thresh, eds. Blackwell Scientific Publications, Oxford.

13. Gamez, R., and Leon, P. 1985. Ecology and evolution of a Neotropical leafhopper-virus - maize association. Pages 331-349 in: The Leafhoppers and Planthoppers. L. R. Nault and J. G. Rodriguez, eds. John Wiley \& Sons Inc., New York.

14. Gamez, R., and Leon, P. 1988. Maize rayado fino and related viruses. Pages 213-233 in: Polyhedral Virions with Monopartite RNA Genomes. R. Koenig, ed. Plenum Press, New York.

15. Gordon, D. T., and Thottappilly, G. 2003. Maize and sorghum. Pages 295334 in: Virus and Virus-like Diseases of Major Crops in Developing Countries. G. Loebenstein and G. Thottappilly, eds. Kluwer Academic Publishers, The Netherlands.

16. Grau, C. R., Radke, V. L., and Gillespie, F. L. 1982. Resistance of soybean cultivars to Sclerotinia sclerotiorum. Plant Dis. 66:506-508.

17. Hammond, R. W., and Bedendo, I. P. 2001. Role of Maize rayado fino virus in the etiology of "red stunt" disease in Brazil. Plant Dis. 85:99.

18. Hammond, R., and Ramirez, P. 2001. Molecular characterization of the genome of Maize rayado fino virus, the type member of the genus Marafivirus. Virology 282:338-347.

19. Jones, M. W., Redinbaugh, M. G., Anderson, R. J., and Louie, R. 2004. Identification of quantitative trait loci controlling resistance to Maize chlorotic dwarf virus. Theor. Appl. Genet. 110:48-57.

20. Jones, M. W., Redinbaugh, M. G., and Louie, R. 2007. The Mdml locus and maize resistance to Maize dwarf mosaic virus. Plant Dis. 91:185-190.

21. Kogel, R., Ramirez, P., and Hammond, R. W. 1996. Incidence and geographic distribution of Maize rayado fino virus (MRFV) in Latin America. Plant Dis. 80:679-683.

22. Louie, R. 1995. Vascular puncture of maize kernels for the mechanical transmission of maize white line mosaic-virus and other viruses of maize. Phytopathology 85:139-143.

23. Louie, R., Abt, J. J., Anderson, R. J., Redinbaugh, M. G., and Gordon, D. T. 2000. Maize necrotic streak virus, a new maize virus with similarity to spe- cies of the family Tombusviridae. Plant Dis. 84:1133-1139.

24. Louie, R., and Anderson, R. J. 1993. Evaluation of Maize chlorotic dwarf virus resistance in maize with multiple inoculations by Graminella nigrifrons (Homoptera: Cicadellidae). J Econ. Entomol. 86:1579-1583.

25. Louie, R., Redinbaugh, M. G., Anderson, R. J., and Jones, M. W. 2002. Registration of maize germplasm Oh1VI. Crop Sci. 42:991.

26. Madriz-Ordenana, K., Thordal-Christensen, H., Collinge, D. B., Ramirez, P., Rojas-Montero, R., and Lundsgaard, T. 2000. Mechanical transmission of maize rayado fino marafivirus (MRFV) to maize and barley by means of the vascular puncture technique. Plant Pathol. 49:302-307.

27. McMullen, M. D., Kresovich, S., Villeda, H. S., Bradbury, P., Li, H., Sun, Q., Flint-Garcia, S., Thornsberry, J., Acharya, C., Bottoms, C., Brown, P., Browne, C., Eller, M., Guill, K., Harjes, C., Kroon, D., Lepak, N., Mitchell, S. E., Peterson, B., Pressoir, G., Romero, S., Rosas, M. O., Salvo, S., Yates, H., Hanson, M., Jones, E., Smith, S., Glaubitz, J. C., Goodman, M., Ware, D., Holland, J. B., and Buckler, E. S. 2009. Genetic properties of the maize nested association mapping population. Science 325:737-740.

28. Nault, L. R., and Bradfute, O. E. 1979. Corn stunt: Involvement of a complex of leafhopper-borne pathogens. Pages 561-586 in: Leafhopper Vectors and Plant Disease Agents. K. Maramorosch and K. F. Harris, eds. Academic Press, New York.

29. Nault, L. R., Gordon, D. T., and Gingery, R. E. 1980. Leafhopper transmission and host range of Maize rayado fino virus. Phytopathology 70:709712.

30. Patterson, H. D., and Williams, E. R. 1976. A new class of resolvable incomplete block designs. Biometrika 63:83-92.

31. Poland, J. A., Pratt, R. C., Nelson, R. J., Balint-Kurti, P., and Wisser, R. J. 2009. Shades of gray: The world of quantitative disease resistance. Trends Plant Sci. 14:21-29.

32. Ramirez Rojas, S., Romero Rosales, F., Dan, J., Martinez Garza, A., and Mejia Andrade, H. 1988. Reacción de ocho variedades de maíz al virus del rayado fino en Chapingo, México. Agric. Tec. Mexico 24:11-18.

33. Redinbaugh, M., and Pratt, R. C. 2009. Virus resistance. Pages 251-268 in: Handbook of Maize: Its Biology. J. L. Bennetzen and S. C. Hake, eds. Springer, New York.

34. Redinbaugh, M. G., Houghton, W., Salomon, R., Creamer, R., Hogenhout, S. A., Gordon, D. T., Ackerman, J., Meulia, T., Seifers, D. L., Abt, J. J., Styer, W. E., and Anderson, R. J. 2002. Maize fine streak virus, a new leafhopper-transmitted rhabdovirus. Phytopathology 92:1167-1174.

35. Silveira, F. T., Moro, J. R., da Silva, H. P., de Oliveira, J. A., and Perecin, D O. L. 2008. Inheritance of the resistance to corn stunt. Pesquisa Agropecuária Bras. 43:1717-1724.

36. Todd, J. C., Hoy, C., Hogenhout, S. A., Ammar, E., and Redinbaugh, M. G. 2010. Plant host range and leafhopper transmission of Maize fine streak virus. Phytopathology 100:1138-1145.

37. Toler, R. W., Harris, K. F., Bockholt, A. J., and Skinner, G. 1985. Reactions of maize (Zea mays) accessions to Maize rayado fino virus. Plant Dis. 69:56-57.

38. Valdez, M., Madriz, K., and Ramírez, P. 2004. A method for genetic transformation of maize for resistance to viral diseases. Rev. Biol. Trop. 52:787 793.

39. Vandeplas, A. 2003. Evaluation of sixty highland elite maize genotypes for resistance to Maize rayado fino virus. The Katholieke Universiteit Leuven, Belgium.

40. Vasquez, J., and Mora, E. 2007. Incidence of and yield loss caused by Maize rayado fino virus in maize cultivars in Ecuador. Euphytica 153:339-342.

41. Yu, J., Buckler, E. S., McMullen, M. D., and Holland, J. B. 2008. Genetic design and statistical power of nested association mapping in maize. Genetics 178:539-511. 